\title{
Correlates of Credit Card Adoption in Urban China
}

PostPrint

For published article see:

Sharpe, D. L., Yao, R., \& Liao, L. (2012). Correlates of credit card adoption in urban China. Journal of Family and Economic Issues, 33(2), 156-166.

\begin{abstract}
Analysis of data from the 2008 Survey of Chinese Consumer Finance and Investor Education indicated that $30.0 \%$ of the sample households held at least one credit card. Significant factors associated with the probability that an urban Chinese individual would hold a credit card included income, age, education, occupation, and awareness of credit card risks, default consequences, the credit system, and that late payments increase interest.
\end{abstract}

Keywords: Chinese, Credit cards, Financial knowledge 


\section{Introduction}

Credit cards, long a part of western consumer markets, have only recently become available to Chinese consumers as a payment mechanism. Worthington (2003) has observed that the history of the credit card in China is unique and distinctly different from that of western industrialized countries or even of near Asian neighbors of Japan, Hong Kong, or Korea. This fact makes it important to examine factors associated with adoption of the credit card by Chinese consumers.

Recent and rapid changes in Chinese financial markets have facilitated entry of the credit card. Following World War II, China had a planned economy under Communist rule. Chinese financial markets were underdeveloped and cash was the main medium of exchange for consumer transactions. In the late 1970s, Chinese Communist leader Deng Xiaoping initiated a series of economic, political, social, and domestic changes during what he termed was a new era of Gaige Kaifang (reforms and openness) (Das 2009). Chinese leadership's express goal was to develop a "socialist market economy”, (DeCosta and Foo 2002).

China's financial sector presented challenges to achieving this goal, however. Evaluating results of China's financial reforms during the 1980s and 1990s, DeCosta and Foo (2002) concluded that at the beginning of the $21^{\text {st }}$ century China's financial system was still " weak and inadequate," noting “The planned distribution of economic resources, particularly credit, [was] contradictory with the structure and functions of a market economy"' (p. 13).

Introduction of the credit card in China involved domestic and foreign banks. The Bank of China, one of the four largest banks in China, offered the first credit cards in China in 1979, acting as an agent for non-Chinese banks such as Chase Manhattan Bank. In June 1985, the Bank of China issued the first domestic credit card named the Great Wall Card. Two years later, the 
Bank of China joined the international credit card associations of Visa and Master- Card and issued the first internationally accepted Great Wall MasterCard in 1988 (Worthington 2003). Between 1987 and 1991, the remaining three of the four largest banks in China had each issued their own credit cards. The large debt burdens of the issuing banks coupled with no nationwide processing and settlement network or credit bureau constrained the features of these early credit cards. Most of these cards did not provide interest free periods or revolving credit. Banks typically required a security deposit or payment guarantee before issuing the card (Worthington 2003).

China had granted entry to foreign banks in the late 1970s as part of their financial reform. But, burdensome administrative and legal regulations created high barriers to entry, discouraging potential entrants and greatly restricting the growth and operations of the foreign banks that did enter. Two decades after foreign banks could enter China, only 190 foreign banks had established operations in China and their collective $\$ 41$ billion in holdings represented only about $2 \%$ of China's total assets (Kynge 2002; Worthington 2003, 2005).

When China joined the World Trade Organization (WTO) in 2001, the accession agreement mandated removal of restrictions on foreign bank operations by 2007. In 2002, Citibank was the first foreign bank that China's central bank, the People's Bank of China, allowed to engage in foreign currency transactions with Chinese citizens. But neither Citibank nor other foreign banks could offer services in domestic currency (Worthington 2003). Although this restriction was lifted in December 2006 (Worthington et al. 2007), limits on such things as bank location and services that could be offered by foreign banks remained.

Relevant to the inception of the credit card market in China was the rule that foreign banks could open only one branch bank per year. In contrast, the four largest domestic banks in 
China had a combined total of 120,000 branch banks throughout China and controlled about 70 $\%$ of domestic bank assets (Worthington 2003). Issuing plastic payment cards in general and credit cards in particular gave foreign banks a means of reaching China's potential 1.3 billion customers while bypassing the Chinese government's restrictive rules for foreign branch bank operation (Worthington 2005).

Initially, credit cards were marketed to high income, high wealth urban Chinese (Worthington et al. 2007). Subsequently, credit card offers were made to young adults, college students, and those with relatively lower income. Between 2004 and 2009, credit card take up in China grew an average of $40 \%$ per year (China Internet Watch 2010). Master Card, Inc, the world's second largest payment network, has forecast that through 2025 the number of Chinese credit cards will increase by $11 \%$ per year and transaction value will increase by $14 \%$ per year. By 2020, China is expected to overtake the US as the largest credit card market in the world with an expected 900 million credit cards in circulation (Bloomberg News 2010).

Currently, little is known about credit card holders in China, especially from a consumer perspective (Liao et al. 2010). A few studies of credit card holders have been conducted to inform bank marketing efforts. In general, these studies have relied on small, convenience, and nonrandom samples. To address this gap in the literature, this study uses data from the 2008 Survey of Chinese Consumer Finance and Investor Education to examine the characteristics and knowledge of Chinese consumers who do and do not hold a credit card. Findings from this study expand what is known about consumer adoption of credit cards in China.

\section{Literature Review}




\section{Characteristics of Credit Card Users}

Kaynak and Harcar (2001) noted that credit card companies issue their cards to a preselected group of individuals. Thus, the demographics of credit card users by and large reflect card issuer policies and criteria. In the growth stages of a credit card market, card companies initially target those likely to have substantial repayment capacity and be seen as trendsetters. This group is typically well-educated, earning high income, and employed in occupations that are esteemed and offer opportunity for spending on business travel, meals, and entertainment. As that market segment becomes saturated, card issuers relax eligibility standards and reach out to other demographic groups such as those with low income or college students (Hayhoe et al. 2000; Kaynak and Harcar 2001; Masuo et al. 2004; Xiao et al. 1993).

Previous research has examined the relationship between credit card usage and gender, education, income, age, and ethnicity. Findings for gender have been somewhat inconclusive. In an early study of credit card users, White (1975) found that single males in the US were more likely to use credit cards than females. In contrast, analyzing data from a random sample drawn from a metropolitan area in the US, Adcock et al. (1977) determined that credit card users were more likely to be female. And, in a study of Turkish consumers, Kaynak et al. (1995) found no significant difference in card holders by gender.

Education level of card holders can be an artifact of the stage of the credit card market in a given locale. Still, there does appear to be a positive relationship between education and credit card use. As previously noted, in the growth stage of the credit card market, the highly educated are courted as customers (Kaynak and Harcar 2001). This fact is affirmed in research by Danes and Hira (1990) who found a significant and positive relationship between degree of credit card use and respondent level of higher education and knowledge of consumer credit. As this 
preferred market became saturated, credit card issuers began to market cards to riskier groups in terms of repayment potential, including those with relatively low income and education and college students (Kaynak and Harcar 2001).

Income has generally been found to have a positive relationship with credit card use (Adcock et al. 1977; Wang et al. 2011; Wasberg et al. 1992). However, as credit card issuers have reached out to a broader demographic, some researchers have found that lower income households use credit cards more than higher income families (Danes and Hira 1990). Credit cards can provide lower income households a line of credit that is either easier to access or lower cost than other potential sources of credit.

Researchers that have surveyed individuals across the lifespan regarding credit card possession and use have generally found that middle-aged household heads were more likely to have and use credit cards. At older ages, however, credit card possession was relatively less frequent (Adcock et al. 1977). In a developing economy, however, the early adopters of credit cards are more likely to be young (Baek and Hong 2004; Kaynak et al. 1995).

\section{Credit Cards in China}

Relatively little research has been conducted on credit card use in China from a consumer perspective. Most existing research informs bank marketing efforts (Worthington 2003, 2005; Worthington et al. 2007). For example, to learn more about the characteristics and behavior of their credit card holders, the Bank of China mailed a questionnaire to 10,000 customers holding their Great Wall credit card in 2000. They received 3,122 completed questionnaires.

Although results were specific to Bank of China customers, the findings gave some insight into card holder characteristics (Worthington 2003, 2005; Worthington et al. 2007). Credit card holders were young ( $67 \%$ of respondents were under age 35 ), highly educated ( $86 \%$ 
of respondents had at least a college education), and relatively affluent ( $70 \%$ of respondents had a monthly income over 2,000 yuan [approximately \$304 USD] and 37 \% of respondents had an income over 3,500 yuan [approximately \$532 USD]). Respondents worked in non-state owned business or foreign-owned companies.

Convenience was the main reason given for card use. Cards were used for shopping (85 $\%$ ) or to avoid carrying a large amount of cash (76\%). Use of a card for hotel, restaurant, and entertainment expenses was common. Bank of China required outstanding balances to be paid in full at the end of the month. About a third of respondents wanted their card to have a line of credit. Other respondents complained that their cards did not have widespread acceptance. A card issued in one province might not be accepted in another province (Worthington 2003).

Extending the Bank of China study, Worthington (2003) asked 20 credit card customers in-depth questions about attitude and use patterns. Respondents said they used their cards largely for safety and convenience. One card holder admitted to using his card to cover "extra expenses" if the daily cash allowance he received from his wife proved to be insufficient. Another respondent stated that using a card made him feel "fashionable," suggesting that card use conveyed social prestige.

Worthington et al. (2007) surveyed a convenience sample of close to 200 MBA students at a major university in China regarding possession and use of credit cards. They found that this group of "early adapters"' as they termed them was comfortable with credit cards. Respondents tended to use their cards to pay for business travel and entertainment expenses. The researchers also found that the respondents were more likely to use credit cards than cash when making a relatively expensive purchase.

\section{Theoretical Framework}


Credit card adoption in a developing country may be considered from more than one theoretical perspective, specifically economics and marketing. Lancaster's model of consumer demand proposes that consumers do not demand a good, per se, but rather desire the various characteristics that good offers them (Lancaster 1966). This model provides a useful conceptual framework for study of credit card adoption and use. Participants in a recent interview of early credit card adopters in China listed several card features that were of interest to them (Worthington et al. 2011). Credit cards provide a convenient payment mechanism, especially for on-line purchases. Credit cards can be safer to carry than large amounts of cash. Monthly statements provide a record of transactions. Some cards offer use incentives such as purchase discounts or points that can be exchanged for goods or services. Credit card use is visible and can give users some degree of social status.

Credit cards also offer payment flexibility. When credit card balances are paid in full each month, no interest charges are incurred. If a balance is carried forward, the credit card becomes an unsecured line of credit and interest accrues on the unpaid balance. Typically such debt is of relative short duration. Participants in Worthington et al.'s (2011) study enjoyed being able to make purchases when cash was not available. They acknowledged, however, if careful attention is not paid to the amount of credit used, overspending could occur.

Existing studies of consumer credit use have typically drawn on the life cycle/permanent income hypothesis $(\mathrm{LCH} / \mathrm{PIH})$ from economics as a theoretical framework (see, for example, Kim and DeVaney 2001, Lyons and Hunt 2003; Lyons 2003). This hypothesis proposes that current household consumption is based on a fraction of households' permanent income (Friedman 1957) or wealth (Ando and Modigliani 1963). Households are assumed to be able to estimate their consumption over the long run and to choose a smooth level of consumption over 
their life time to maximize utility. Debt financing facilitates consumption smoothing. Households are expected to borrow when the household head is young, repay debt and save during mid-life and dissave during the retirement years. Thus, the LCH/PIH highlights the relationship between life cycle stage and demand for credit (Baek and Hong 2004).

Modigliani and Cao (2004) used the LCH/PIH to explain the extremely high rate of savings in China despite the country's relatively low and slow income growth. This work countered the long standing opinion among economists that the $\mathrm{LCH} / \mathrm{PIH}$ only applied to developed market economies. Although China has made rapid progress toward a market economy, it is still considered a developing country (Worthington et al. 2007).

Given China's long-standing norms against holding debt, however, the LCH/PIH might not provide an adequate explanation of reasons for credit card adoption in this study. For card holders who do not carry a balance, the credit card is not a debt instrument. Rather, it becomes the functional equivalent to cash, a debit card, or a check. Therefore, it becomes helpful to also consider marketing theory as a means of explaining credit card adoption.

Marketing theory highlights the importance of information and experience in the adoption of innovation. Wozniak (1987) describes adopting an innovation as a "reallocation decision made in response to disequilibria" that was created by changed opportunities and risks in the market (p. 102). Although Wozniak was referring to innovation in general, his observation has relevance to the introduction of a new payment mechanism in a developing market economy.

Prior to introduction of plastic cards in general and credit cards in particular, Chinese consumers transacted business in cash, due both to underdeveloped capital markets and to centuries of Confucian teaching to shun debt (Evans 2008; Worthington 2005). The credit card brought technological innovation to the consumer payment market, creating new opportunities as 
well as uncertainties. Advantages such as convenience in making payments and reduced need to carry cash could entice credit card adoption. Conversely, uncertainty regarding the process and outcome of card use as well as a cultural aversion to debt could discourage adoption.

Barker and Sekerkaya (1992) underscored the fact that credit card take up in developing countries differs markedly from that of developed markets. Developing countries lack technological infrastructure for credit card use such as ATMs or point of sale systems that both support and encourage credit card use. This fact tends to slow widespread distribution of credit cards. In addition, they noted:

Use of the credit card requires the buyers to act in drastically new ways, change their way of thinking and modify their behaviour (sic) patterns radically in developing countries.... In an environment where cheque (sic) usage is rather limited, the credit card is both a prestigious novelty and a source of risk for the consumer... (Barker and Sekerkaya 1992: p. 28).

Their observation echoes Wozniak's comment regarding innovation. Before consumers can change thought and behavior, product information is needed. Thus, in this study consumer credit card knowledge is also considered as a factor influencing credit card take-up.

\section{Hypotheses}

The relationship between income and credit card holding in China is subject to two different and conflicting influences. The LCH/PIH suggests that, among households that use debt to smooth lifetime consumption, borrowing should occur when income is low and debt pay down should occur when income is high. Consequently, from an economic perspective income should have a negative effect on the likelihood of credit card ownership. 
However, access to unsecured credit is only one aspect of credit card use and not one which all card carriers might choose to utilize, especially in a saving centric country such as China. Credit card companies initially market to the affluent, a group likely to be actively engaged in consumption, and be seen as the group to emulate. Thus, from a marketing perspective, income would be expected to be positively related to credit card ownership.

In general, it would be expected that households with financial dependents, whether children or elders, and relatively large households would have more consumption needs. Therefore, these households are expected to be more likely to utilize credit cards to finance the correspondingly greater consumption needs.

In a developing country such as China, credit cards represent an entirely new payment mechanism. Introduction of this payment mechanism during a transitional period in the financial market would mean that understanding of credit card characteristics by Chinese consumers would be quite limited. Younger people are expected to be more likely to be willing to adopt the new payment mechanism. Therefore, age is expected to have a negative relationship with probability of credit card ownership. It is also expected that willingness to replace the longstanding practice of using cash with a credit card would be linked to gaining knowledge of credit card features. Consequently, it is hypothesized that having knowledge of salient credit card features would increase the likelihood of holding them.

\section{Empirical Methodology}

\section{Data}

A research team at a major research university in China designed and conducted a national survey on Chinese consumer finance in 2008. Survey questions were similar to those 
used in the US Survey of Consumer Finances and to the Acorn Marketing and Research Consultant's Income and Expenditure Survey in Singapore. Given the prudent culture in China, survey respondents are generally quite circumspect in giving detailed personal information to anyone that they do not know. Therefore, most variables were structured as categorical in an attempt to reduce refusal to participate (Liao et al. 2010).

The research team employed the probability proportional to size (PPS) without replacement method to select sample households. Based on their administrative division, cities can be divided into three types: (1) municipalities directly under the Central Government (mayor is equal in status to a governor of a province); (2) sub-provincial cities (mayor is equal in status to the vice-governor of a province); and (3) prefecture- level cities (administrative rank is between a province and a county). Two out of a total of four municipalities directly under the Central Government, five out of a total of 15 sub-provincial cities, and eight out of a total of 268 cities at the prefecture level were selected. As a result, 15 cities, located in the East, Central, West, and Northeast part of China, were selected to reach a geographically representative sample of Chinese urban households. Households were randomly sampled from these cities.

A "'household"' was defined as a single individual or a core couple and all other individuals living in the household that were financially interdependent. The respondent in each household was the person most knowledgeable about the household finances and the major household financial decision-maker. A random sample of 2,095 urban households from 15 cities participated in face-to-face interviews. Survey questions gathered information on household demographic characteristics, balance sheet and income and expense statement items, credit knowledge and management, retirement and estate plans. 
The proportion of cities selected from each of the three levels varied (two out of four type 1 cities, five out of 15 type 2 cities, and eight out of 268 type 3 cities). The number of sample households selected from each city also differed. As such, a weight variable was constructed and recommended by the research team to be used in the descriptive analyses so that the results from the analyses of the sample households would be representative of the total population of Chinese urban households (see Liao et al. 2010 for more details on the construction of this weight variable).

\section{Variables}

The dependent variable was whether the respondent owned at least one credit card (1 if yes, 0 otherwise). Independent variables were chosen from both economic and marketing theories and prior empirical research related to credit card take up and use. Demographic characteristics were used to identify life cycle stage. These characteristics included the household type, presence of financially dependent children and elders, and household size, all of which were categorical variables. Respondents were divided into three age groups: under 35 (reference group), 35-50, and over 50, denoting young adult, mid-life and later life. Depending on the gender and marital status of the respondent, households were divided into three groups: a married couple, an unmarried male, or an unmarried female. Presence of financially dependent children or financially dependent elders ( 1 if yes, 0 otherwise) and household size ( 1 is the reference group, other categories are 2, 3, or 4 or more) were also included as independent variables to control for lifecycle stage.

Education categories included less than high school (reference group), high school, some college or bachelor's degree, and graduate degree. Occupation included government employees 
(reference group), professionals, blue collar workers, self-employed individuals, freelance workers, and others (including those retired and not currently working).

Economic characteristics included amount of household annual after-tax income, categories of net worth (lowest quartile is the reference group, other categories are second, third, and highest quartiles), and home ownership ( 1 if yes, 0 otherwise). Household annual after-tax income was a continuous variable. A log transformation was used in the empirical analysis to examine the effect of each additional percent of income on credit card holding.

Credit card knowledge was assessed by respondent affirmation or denial of knowledge of credit card risk, consequences of defaulting on payments, the national credit system in China, penalty on a cash advance, and the fact that interest increases following a late payment ( 1 if yes, 0 otherwise).

\section{Statistical Method}

To observe the percent distribution of credit card ownership in various age groups stratified by credit card knowledge, cross-tabulations of credit card ownership and knowledge related to credit cards for each of the three age groups were conducted. Percentage distributions were calculated to learn more about the reasons for holding a credit card and frequency of different types of use. Logistic regression analysis was used to determine the extent to which respondents' knowledge of credit cards and household demographic and economic characteristics affect the likelihood that respondents will have a credit card. A p-value less than 0.05 was interpreted as statistically significant.

Households with missing values (24 cases) were excluded from this study. As a result, the total sample size was 2,071 for the descriptive and multivariate analyses. 


\section{Results}

\section{Characteristics of Sample Households}

Considering the sample as a whole, the median age of respondents was between 35 and 40. The median household size was 3 . Most respondents $(62.4 \%)$ did not go to college. Annual household after-tax income ranged from 1,200 yuan (approximately \$182 USD) to 1,500,000 yuan (approximately \$227,933 USD). The distribution of household after-tax income was highly skewed to the right with a mean of 62,632 yuan (approximately $\$ 9,527$ USD), and a median of 40,000 yuan (approximately $\$ 6,078$ USD). Home ownership rate was $85.0 \%$.

As shown in Table 1, a majority of respondents $(70.1 \%)$ did not have a credit card. Among respondents who had at least one credit card, most were younger than 35 (58.1\%). Credit card owners were more likely than those without a credit card to have knowledge related to credit cards. For example, $80.2 \%$ of credit card owners were aware of the consequences of being in default on payments. In contrast, only $37.8 \%$ of those with no credit card reported an awareness of such consequences. Those who had at least some college education were more likely to have a credit card than those with a lower education. Among credit card owners, $61.8 \%$ had some college or more education. However, among those who did not have a credit card, 48.0 $\%$ had graduated from high school and $24.6 \%$ had less than a high school education. On average, credit card owners received higher after-tax income (90,451 yuan) than those without a credit card (50,833 yuan).

In general, credit card ownership appears related to age. Among those who had at least one credit card, $58.1 \%$ were under age 35 whereas $3.2 \%$ were older than 50 (see Table 1). Since data are cross sectional, the age differences could be due to either generational differences or life cycle differences. 
Knowledge related to credit cards by age and credit card ownership is detailed in Table 2. Those who had a credit card were generally more informed about credit card characteristics. For example, across the three age groups there were between 83.3 and $92.9 \%$ of credit card holders that were aware of the general risk of using credit cards; whereas for those without a credit card, the percentages ranged from 33.7 to $55.2 \%$.

Among those who had a card, the oldest age group was the most likely to report that they are very well aware of the general risks of using credit cards ( 40.0 vs. $25.3 \%$ of the youngest age group and $34.2 \%$ of the $35-50$ age group, differences statistically significant at the .01 level). However, across the age groups for credit card holders there was no statistically significant difference in the awareness of other aspects of card use. It appears that the overwhelming majority of credit card holders were well informed on both general knowledge and details related to credit cards.

Those who did not have a credit card were found to be much less conversant regarding credit card characteristics. Most of these respondents did not know there was a credit system, nor were they aware of the consequences of being in default or that there was a penalty for taking a cash advance. A significantly higher percentage of the oldest age group (66.3\%) reported being unaware of the general risk of using credit cards as compared with the younger groups ( $44.8 \%$ for the 35 age group and $55.7 \%$ for the $35-50$ age group). The awareness of the consequences of being default on payments and the national credit system were also lower for the older age group.

Among those who did not have a card, $72.0 \%$ reported that they did not need to use credit cards (Table 3$)$. Some non-owners $(11.4 \%)$ had concerns regarding the potential to overspend whereas others were concerned about safety issues ( $8.5 \%)$ or found the application 
process too complicated (6.3\%). About half of credit card holders (48.5\%) had credit cards because this payment type was required for some purchases. A quarter of credit card holders ( $25.1 \%)$ had credit cards because they could provide easy access to a loan. Bank promotion was the reason given by $23.5 \%$ of the holders to have credit cards. Credit cards were mostly used for in-store purchases $(52.7 \%)$ rather than online purchases $(9.4 \%)$. Most credit card holders believed they had adequate credit (79.2\%) although a few reported that they had too much credit (3.9\%). However, $16.3 \%$ of the holders reported a desire for more credit. Most credit card holders (71.9\%) were never late on credit card payments. Among those who were late, $5.8 \%$ reported cash flow issues whereas others reported that they simply forgot to pay. Two-fifths of credit card holders (43.6\%) used cash to pay credit card balances; $30.5 \%$ utilized automatic transfers; and $25.5 \%$ manually transferred from a bank account on the due date. A little over half of credit card holders (54.9\%) paid the full balance and $27.0 \%$ paid the minimum payments. Among credit holders, $69.8 \%$ believed that using credit cards contributed to their overspending.

\section{Multivariate Results}

Income had a significant and positive effect on the likelihood of credit card ownership. A $1 \%$ increase in income increased the likelihood of having credit cards by $0.4 \%$ (Table 4 ). This finding is not consistent with the $\mathrm{LCH} / \mathrm{PIH}$, but is consistent with the marketing practice of targeting those with high income for initial dispersal of credit cards in a given market.

Our hypothesis on the effect of consumption needs was not supported. Household size and the presence of financial dependents did not significantly affect the likelihood of having a credit card. All else equal, the $35-50$ age group was $65 \%$ as likely to own a credit card as the youngest age group, whereas the[50 group was only $19 \%$ as likely. This result confirmed our 
hypothesis that younger individuals would be more likely to be credit card adopters from having relatively greater openness to market innovation.

The multivariate analysis focused on general credit card knowledge, in particular knowing consequences of default and how to establish a credit record. It was reasoned that it was not likely for those with no credit card experience to be aware of penalties for cash advance or an increase in interest charges after a late payment.

Multivariate results indicate that credit card ownership is associated with general credit card information and experience in the adoption of innovation. Those who were well aware of the general risk of using credit cards were $397 \%$ more likely to own a credit card than those who were unaware of the risk. Those who were aware of the consequences of default were $170 \%$ more likely to own a credit card than those who were unaware of the consequences. Respondents who reported knowledge of the national credit system were $77 \%$ more likely to have a credit card as compared with those that did not have that knowledge.

Education was found to be positively related to the probability of holding credit cards. Those with some college or a bachelor's degree were $107 \%$ more likely and graduate degree holders were $271 \%$ more likely to have a credit card than those who did not complete high school. Occupation mattered. Blue collar workers, freelance workers and others were less likely to have a credit card than government employees. Separate logistic analyses with different occupation reference groups were conducted (results not reported here). Respondents in occupational categories not explicitly identified (the "others" category) were significantly less likely than the rest of the groups to have a credit card. 
Wealth had a limited influence on credit card holding. Those with net worth in the highest quartile were $76 \%$ more likely than those with net worth levels in the lowest quartile to have a credit card. Home ownership, however, was not a significant factor.

\section{Discussion and Implications}

Recent introduction of the credit card in China creates interest in the characteristics of consumers who do and who do not adopt this payment option. This study uses a random sample of urban Chinese residents to gain some insight into those characteristics and extend application of economic and marketing theory to an international context.

Income level was negatively related to credit card ownership. This result did not support the life cycle hypothesis, but did support the marketing perspective that credit card issuers target the relatively more affluent in initial credit card offerings. As expected, the relationship between age and likelihood of having credit cards was negative. This finding suggests that younger individuals are more open to adopting a credit card as a new payment system.

Marketing theory posits that knowledge also facilitates adoption of a new technology. Consistent with this theory and, as hypothesized, having knowledge of general credit card characteristics was positively related to the likelihood of having credit cards. It should be noted, however, that it is not possible to determine causality with certainty using cross-sectional data. It could also be argued that knowledge of credit card characteristics is acquired via obtaining and using credit cards and interacting with the credit card market.

Of some concern is the finding that, among those with credit cards, a substantial proportion reported they had no knowledge of critical credit card features. Across all age groups, around one in ten were not aware of credit card risk or of interest increases after a late payment. Close to one in five were not aware of the consequences of default or the penalty for a cash 
advance. Over three in ten had no knowledge of the new national credit system. Not knowing or understanding these important credit card features can contribute to credit card mismanagement and consequent financial distress.

A clear implication of this research is that the Chinese population needs information regarding the benefits and risks of credit financing. China is rapidly transitioning from a command to a market economy (Worthington et al. 2011). Consumer spending is increasing and consumer saving is decreasing. Total sales of consumer goods in China increased $14.8 \%$ between 2009 and 2010 (Gang 2011). Between 2004 and 2011, the savings rate in China dropped from 26 to $12 \%$ (China Internet Watch 2011). Credit Suisse, a global financial services company, expects that by 2020 China will overtake the US as the largest consumer market in the world (China Internet Watch 2011).

Credit and debt are relatively new concepts to the Chinese culture (Chen 2004; Worthington et al. 2011). The ethos of buy now, pay later that is associated with the credit card defies centuries of Confucian teaching regarding thrift, avoidance of debt, and saving for the future. Thus, the credit card has introduced a way of life and a financial behavior that is antithetical to prevailing Chinese culture (Evans 2008; Worthington et al. 2011).

Long accustomed to cash-only transactions, some consumers have found themselves illprepared to manage consumer debt. In July 2009, concerned about rising credit delinquency, the China Banking Regulatory Commission demanded that banks not offer gifts to new credit card holders, set sales quotas or issue cards to persons under age 18 (Wei and Chien 2009). Despite these restrictions, in the first quarter of 2010, the People's Bank of China reported that mainland Chinese credit card debt rose just over $14 \%$ (China Briefing 2010). 
Excessive debt loads can threaten the financial security of individuals and their families. Wei and Chien (2009) report a retiree cut up his adult son's seven credit cards when he learned that his son had amassed credit card debt that he could not repay. The father used most of his life savings to reduce his son's credit card bill by about half. Situations such as this underscore the critical importance of consumer credit education, especially as China's vast population and credit card marketers are expected to make China the world's largest credit card market by 2020, less than a decade from now.

A clear limitation of this study is that it focused on urban households in China. Sun and $\mathrm{Wu}$ (2004) suggest that urban versus rural residence is a more meaningful classification, citing the distinct differences in the level of economic development and consumer sophistication in the two locales. The majority of Chinese population resides in rural areas. Future research is needed to compare the differences between rural and urban households in credit card ownership and usage, especially when the credit card industry is proliferating in China. During the credit take up process in the country, China still does not have the same degree of consumer protection in the credit markets as in the US. Future research is called for to help policy makers in China to design and provide such protection to consumers. 


\section{References}

Adcock, W. O., Hirschman, E. C., \& Goldstucker, J. L. (1977). Bank credit card users: An updated profile. Advances in Consumer Research, 4, 236-241.

Ando, A., \& Modigliani, F. (1963). The life cycle hypothesis of saving: Aggregate implications and tests. American Economic Review, 53(1), 55-84.

Baek, E., \& Hong, G. (2004). Effect of family life cycle states on consumer debts. Journal of Family and Economic Issues, 25(3), 359-385.

Barker, T., \& Sekerkaya, A. (1992). Globalization of credit card usage: The case of a developing economy. International Journal of Bank Marketing, 10(6), 27-31.

Bloomberg News. (2010). China to pass US as largest credit-card market by 2020, MasterCard says, September 10. Retrieved Oct 26, 2011 from http://www.bloomberg.com/news/2010-09-10/ china-to-pass-u-s-as-largest-credit-cardmarket-by-2020-master card-says.html.

China Briefing. (2010). China credit card debt increases. Retrieved Oct 26, 2011 from http://www.uslaw.com/library/International_Law/China_Credit_Card_Debt_Increases.ph p?item $=804611$.

China Internet Watch. (2010). Growing adoption of credit card in China. Retrieved Oct 26, 2011 from http://www.chinainternet watch.com/734/credit\%20card/.

China Internet Watch. (2011). Chinese households earning more but saving less. Retrieved Feb 29, 2012 from http://www.chinainternetwatch.com/934/chinese-households-earningmorebut-saving-less/.

Chen, W. (2004). Comparison of Chinese and US credit system and suggestions. Study on China Administration for Industry and Commerce, 13(8), 8-12. 
Danes, S. M., \& Hira, T. K. (1990). Knowledge, beliefs, and practices in the use of credit cards. Home Economics Research Journal, 18, 223-235.

Das, S. (2009). The China syndrome and the crisis. Business Day. Retrieved Oct 26, 2011 from http://www.smh.com.au/business/ the-china-syndrome-and-the-crisis-20091227lg83.html.

DeCosta, M., \& Foo, J. (2002). China's financial system: Two decades of gradual reforms. Managerial Finance, 28(10), 3-18.

Evans, J. W. (2008). Challenging confucius: Western banks in the Chinese credit card market. Business Horizons, 51, 519-527.

Friedman, M. (1957). A theory of the consumption function. Princeton, NJ: Princeton University Press.

Gang, F. (2011). The yen for city life, not the yuan, will solve China's trade imbalance. Retrieved Feb 29, 2012 from http://newsstore. theage.com.au/apps/viewDocument.ac?multiview=true $\&$ sy=age \&page $=1 \& \mathrm{kw}=$ gang\&pb $=$ all_ff $x \& \mathrm{dt}=$ selectRange $\& \mathrm{dr}=2 \mathrm{years} \&$ $\mathrm{so}=$ relevance $\& \mathrm{sf}=$ author $\& \mathrm{rc}=200 \& \mathrm{rm}=200 \& \mathrm{sp}=\mathrm{nrm} \& \mathrm{clsPage}=$ 1\&hids=\&sids=AGE1 10203RV7N15323KE\#.

Hayhoe, C. R., Leach, J. J., Turner, P. R., Bruin, M. J., \& Lawrence, F. C. (2000). Differences in spending habits and credit use of college students. Journal of Consumer Affairs, 34(1), $113-134$.

Kaynak, E., \& Harcar, T. (2001). Consumers' attitudes and intentions towards credit card usage in an advanced developing country. Journal of Financial Services Marketing, 6(1), 24-38. 
Kaynak, E., Kucukemiroglu, O., \& Ozmen, A. (1995). Correlates of credit card acceptance and use in an advanced developing middle Eastern country. Journal of Service Marketing, $9(4), 52-63$.

Kim, H., \& DeVaney, S. A. (2001). The determinants of outstanding balances among credit card revolvers. Financial Counseling and Planning, 12, 67-77.

Kynge, J. (2002). Expectations look set to outstrip the reality. The Financial Times, China and the WTO, 15 March, p. V.

Lancaster, K. J. (1966). A new approach to consumer theory. Journal of Political Economy, 74, 132-157.

Liao, L., Huang, N., \& Yao, R. (2010). Family finance in urban China: Evidence from a national survey. Journal of Family and Economics, 31, 259-279.

Lyons, A. C. (2003). How credit access has changed over time for U.S. households. Journal of Consumer Affairs, 37(2), 231-255.

Lyons, A. C., \& Hunt, J. L. (2003). The credit practices and financial education needs of community college students. Financial Counseling and Planning, 14(1), 63-74.

Masuo, D. M., Malroutu, Y. L., Hanashiro, R., \& Kim, J. H. (2004). College students' money beliefs and behaviors: An Asian perspective. Journal of Family and Economic Issues, 24(4), 469-481.

Modigliani, F., \& Cao, S. L. (2004). The Chinese saving puzzle and the life-cycle hypothesis. Journal of Economic Literature, XLII, 145-170.

Sun, T., \& Wu, G. (2004). Consumption patterns of Chinese urban and rural consumers. Journal of Consumer Marketing, 21(4), 245-253. 
White, K. J. (1975). Consumer choice and use of bank credit cards: A model and cross-section results. Journal of Consumer Research, 2(1), 10-18.

Wang, L., Lu, W., \& Malhotra, N. K. (2011). Demographics, attitude, personality and credit card features correlate with credit card debt: A view from China. Journal of Economic Psychology, 32, 179-193.

Wasberg, C. A., Hira, T. K., \& Fanslow, A. M. (1992). Credit card usage and consumer debt of households. Journal of Consumer Studies and Home Economics, 16, 19-32.

Worthington, S. (2003). The Chinese payment card market: An exploratory study. The International Journal of Bank Marketing, 21(6/7), 324-334.

Worthington, S. (2005). Entering the market for financial services in transitional economies: A case study of credit cards in China. The International Journal of Bank Marketing, 23(4/5), $381-396$.

Worthington, S., Stewart, D., \& Lu, X. (2007). The adoption and usage of credit cards by urbanaffluent consumers in China. International Journal of Bank Marketing, 25(4), 238-252.

Worthington, S., Thompson, F. M., \& Stewart, D. (2011). Credit cards in a Chinese cultural context — the young, affluent Chinese as early adopters. Journal of Retailing and Consumer Services, 18, 534-541.

Wozniak, G. D. (1987). Human capital, information, and the early adoption of new technology. The Journal of Human Resources, 22(1), 101-112.

Wei, M., \& Chien, K. (2009). China cracking down on credit card issuers. The New York Times. Retrieved Oct 26, 2011 from http://www.nytimes.com/2009/08/14/business/global/14card.html?_r=1\&pagewanted=pri nt. 
Xiao, J. J., Noring, F. E., \& Anderson, J. G. (1993). College students' attitudes towards credit cards. Journal of Consumer Studies and Home Economics, 19, 155-174.

Table 1 Characteristics of sample households by credit card ownership

\begin{tabular}{|c|c|c|}
\hline Sample characteristics & $\begin{array}{l}\text { Have credit } \\
\text { card }\end{array}$ & $\begin{array}{l}\text { No credit } \\
\text { card }\end{array}$ \\
\hline \multicolumn{3}{|l|}{ Age $(\%)$} \\
\hline$<35$ & 58.1 & 36.6 \\
\hline $35-50$ & 38.7 & 44.2 \\
\hline$>50$ & 3.2 & 19.2 \\
\hline \multicolumn{3}{|l|}{ Awareness of credit card risk (\%) } \\
\hline Very well & 29.2 & 8.5 \\
\hline Some & 58.1 & 37.8 \\
\hline No & 12.7 & 53.8 \\
\hline Awareness of consequences of default & 80.2 & 37.8 \\
\hline $\begin{array}{l}\text { Knowledge of new national credit } \\
\text { system }\end{array}$ & 66.1 & 28.5 \\
\hline Awareness of penalty of cash advance & 80.6 & 47.7 \\
\hline \multicolumn{3}{|c|}{ Awareness of interest increase after a late payment (\%) } \\
\hline Yes & 73.5 & 32.5 \\
\hline No & 11.8 & 38.7 \\
\hline Maybe & 14.7 & 28.8 \\
\hline \multicolumn{3}{|l|}{ Education (\%) } \\
\hline Less than high schod & 4.7 & 24.6 \\
\hline High school & 33.5 & 48.0 \\
\hline Bachelor degree or some college & 57.3 & 26.5 \\
\hline Graduate degree & 4.5 & 0.9 \\
\hline \multicolumn{3}{|l|}{ Household type (\%) } \\
\hline Unmarried male & 14.2 & 9.8 \\
\hline Unmarried female & 14.4 & 10.6 \\
\hline Married & 71.5 & 79.6 \\
\hline Presence of related children & 61.3 & 58.6 \\
\hline \multicolumn{3}{|l|}{ Household size (\%) } \\
\hline 1 & 2.1 & 3.1 \\
\hline 2 & 11.1 & 13.7 \\
\hline 3 & 49.0 & 47.0 \\
\hline$\geq 4$ & 37.7 & 36.2 \\
\hline \multicolumn{3}{|l|}{ Employment status } \\
\hline Salary eamer (\%) & 71.6 & $\$ 2.9$ \\
\hline Self-employed (\%) & 23.9 & 26.6 \\
\hline No working (\%) & 4.5 & 20.5 \\
\hline After-tax income (mean) & $\begin{array}{r}90,451 \\
\text { ywan }\end{array}$ & $\begin{array}{r}50,833 \\
\text { ywan }\end{array}$ \\
\hline \multicolumn{3}{|l|}{ Net warth } \\
\hline Lowest quartile (\%) & 16.1 & 29.0 \\
\hline Second quartile (\%) & 22.7 & 32.3 \\
\hline Third quartile (\%) & 26.3 & 23.6 \\
\hline Highest quartile (\%) & 34.8 & 15.1 \\
\hline Home ownership (\%) & 87.3 & 84.0 \\
\hline Total & 620 & 1,451 \\
\hline
\end{tabular}


Table 2 Credit card knowledge by age and credit card ownership

\begin{tabular}{|c|c|c|c|c|c|c|}
\hline \multirow[t]{3}{*}{ Credit card knowledge } & \multicolumn{3}{|c|}{ Have credit card } & \multicolumn{3}{|c|}{ No credit card } \\
\hline & \multicolumn{3}{|l|}{ Age } & \multicolumn{3}{|l|}{ Age } \\
\hline & $<35$ & $35-50$ & $>50$ & $<5$ & $35-50$ & $>50$ \\
\hline Awareness of credit card risk & ** & & & *** & & \\
\hline Very well (\%) & 25.3 & 34.2 & 40.0 & 9.2 & 8.0 & 8.2 \\
\hline Some $(\%)$ & 58.1 & 58.8 & 50.0 & 46.0 & 36.4 & 25.5 \\
\hline No $(\%)$ & 16.7 & 7.1 & 10.0 & 44.8 & 55.7 & 66.3 \\
\hline Awareness of consequences of default & & & & $*$ & & \\
\hline Yes $(\%)$ & 79.2 & 81.7 & 80.0 & 41.2 & 37.8 & 31.5 \\
\hline No $(\%)$ & 20.8 & 18.3 & 20.0 & 58.8 & 62.3 & 68.5 \\
\hline Knowledge of new national credit system & & & & *** & & \\
\hline Yes $(\%)$ & 63.6 & 70.4 & 60.0 & 33.3 & 28.7 & 18.6 \\
\hline No $(\%)$ & 36.4 & 29.6 & 40.0 & 66.7 & 71.3 & 81.4 \\
\hline \multicolumn{7}{|l|}{ Awareness of penalty of cash advance } \\
\hline Yes $(\%)$ & 80.6 & 82.1 & 65.0 & 49.2 & 49.3 & 41.2 \\
\hline No $(\%)$ & 19.4 & 17.9 & 35.0 & 50.9 & 50.7 & 58.8 \\
\hline \multicolumn{7}{|c|}{ Awareness of interest increase after a late payment } \\
\hline Yes $(\%)$ & 71.7 & 76.7 & 70.0 & 36.2 & 32.3 & 26.2 \\
\hline No $(\%)$ & 11.7 & 11.3 & 20.0 & 36.5 & 38.5 & 43.0 \\
\hline Maybe (\%) & 16.7 & 12.1 & 10.0 & 27.3 & 29.2 & 30.8 \\
\hline \multirow[t]{2}{*}{ Total } & 360 & 240 & 20 & 531 & 641 & 279 \\
\hline & $17.4 \%$ & $11.6 \%$ & $1.0 \%$ & $25.6 \%$ & $31.0 \%$ & $13.5 \%$ \\
\hline
\end{tabular}

${ }^{*} p<.05,{ }^{* *} p<.01,{ }^{* * *} p<.001$ 
Table 3 Credit card bolding and usage

Percentage

Asked of non-card holders

Reasons for not having a credit card

Safety

8.5

High threshold and complicated process 6.3

No need 72.0

Possibility to overspend $\quad 11.4$

Failed application $\quad 1.7$

No response $\quad 0.2$

Asked of card holders

Reasons to hold credit card

Bank promotion

23.5

Easy access to loans $\quad 25.1$

Special payment requirement 48.5

Other 3.8

Frequency of using credit card for purchases in store Always

52.7

Seldom 43.5

No $\quad 3.6$

No response $\quad 0.3$

Frequency of using credit card for purchases online

Always

Seldom 40.9

No $\quad 49.6$

No Response

Frequency of using credit card as a way to obtain temporary loan

Always $\quad 5.0$

Seldom 28.0

No 66.9

No response $\quad 0.2$

Frequency of using credit card to pay balance on another credit card Always $\quad 5.3$

Seldom 22.8

No 71.2

No Response $\quad 0.7$

Do you think you have adequate credit?

No

16.3

Ok

79.2

Too much

3.9

No Response

Have you been late on payments?

No

71.9

Sometimes

26.8

Always

No Response

1.0

0.3

Reasons for bate payments

Sometimes forgot

89.2

Usually forg $\alpha$

Cash flow issues

\section{年}

2

.7

\section{Table 3 continued}

\begin{tabular}{lc}
\hline & Percentage \\
\hline How do you pay the credit card bill? & 30.5 \\
Autonatic transfer from bank accounts & 25.5 \\
Manually transfer on the due date & 43.6 \\
Cash & 0.3 \\
No response & \\
Payment amount & 27.0 \\
Minimum payment amount & 54.9 \\
Full balance & 17.5 \\
Between minimum amount and full balance & 0.7 \\
No response & \\
Did credit card stimulate overspending? & 8.9 \\
Very much & 60.9 \\
Some & 30.1 \\
No & 0.2 \\
No response &
\end{tabular}


Table 4 Logistic Analysis of the Likelihood of Holding Credit Cards

\begin{tabular}{|c|c|c|c|}
\hline \multirow[t]{2}{*}{ Sample characteristics } & \multicolumn{3}{|c|}{ Credit cards } \\
\hline & \multicolumn{2}{|c|}{ Coefficients } & \multirow{2}{*}{$\begin{array}{l}\text { Odds } \\
\text { ratio }\end{array}$} \\
\hline Intercept & -7.134 & $* * *$ & \\
\hline Log(income) & 0.407 & $* * *$ & $\mathrm{n} / \mathrm{a}$ \\
\hline Presence of dependent children & 0.023 & & 1.02 \\
\hline Presence of dependent elders & 0.197 & & 1.22 \\
\hline \multicolumn{4}{|c|}{ Household size (reference category: 1) } \\
\hline 2 & 0.367 & & 1.44 \\
\hline 3 & 0.456 & & 1.58 \\
\hline$\geq 4$ & 0.269 & & 1.31 \\
\hline \multicolumn{4}{|l|}{ Age (reference category: $<35$ ) } \\
\hline $35-50$ & -0.425 & $* *$ & 0.65 \\
\hline$>50$ & -1.638 & $* * *$ & 0.19 \\
\hline
\end{tabular}

Awareness of credit card risk (reference category: no)

$\begin{array}{lccc}\text { Very well } & 1.603 & * * * * & 4.97 \\ \text { Some } & 1.097 & * * * * & 2.99 \\ \text { Awareness of consequences of default } & 0.992 & * * * * & 2.70 \\ \text { Knowledge of new national credit system } & 0.569 & * * * * & 1.77 \\ \text { Education (reference category: less than high school) } & & \\ \text { High School } & 0.343 & & 1.41 \\ \text { Bachelor or some college } & 0.727 & * * * & 2.07 \\ \text { Graduate degree } & 1.310 & * * * & 3.71\end{array}$

Occupation (reference category: govemment employees)

$\begin{array}{llll}\text { Professionals } & -0.514 & & 0.60 \\ \text { Blue collar workers } & -0.619 * & 0.54 \\ \text { Self-employed } & -0.529 & & 0.59 \\ \text { Free lance } & -0.733 * * & 0.48 \\ \text { Other } & -1.568 * * * * & 0.21\end{array}$

Household type (reference category: married)

$\begin{array}{lll}\text { Unmarried male } & -0.105 & 0.90 \\ \text { Unmarried female } & 0.305 & 1.36\end{array}$

Net worth (reference category: lowest quartile)

\begin{tabular}{|c|c|c|c|}
\hline Second quartile & -0.018 & & 0.98 \\
\hline Third quartile & -0.001 & & 1.00 \\
\hline Highest quartile & 0.564 & $*$ & 1.76 \\
\hline Home ownership & 0.013 & & 1.01 \\
\hline Concordance & 85.6 & & \\
\hline Chi-sq test of likelihood ratio & 775.72 & $* * *$ & \\
\hline
\end{tabular}

${ }^{*} p<.05,{ }^{* * *} p<.01,{ }^{* * *} p<.001$ 